\title{
The benefit of interferon induction dose in the treatment of chronic hepatitis C patients
}

\author{
Johannes Hudyono
}

\begin{abstract}
Abstrak
Perkembangan pengetahuan tentang aspek biologi virus hepatitis $C$ memungkinkan penemuan rejimen pengobatan alternatif. Interferon (IFN) alfa merupakan satu-satunya obat yang diakui untuk pengobatan hepatitis virus C kronik (HCV), namun angka kekambuhan setelah penghentian terapi tiga kali seminggu pada pasien-pasien ini mencapai $50 \%$. Beberapa peneliti telah membuktikan bahwa mutasi virus dapat terjadi selama pengobatan dengan rejimen tiga kali seminggu. Hal ini berkaitan dengan produksi HCV yang tinggi dan menunjukkan bahwa rejimen alternatif dengan dosis induksi harian mungkin efektif dalam mencegah mutasi. Alasan untuk memberikan dosis induksi harian adalah agar obat secara cepat mencapai konsentrasi 'steady state' yang diharapkan dapat menghambat replikasi virus secara lengkap dan meminimalkan resiko mutasi seperti yang terlihat pada pemberian intermiten tiga kali seminggu. Beberapa peneliti akhir-akhir ini melaporkan bahwa pasien dengan respon permanen terhadap IFN juga menunjukkan eradikasi virus secara cepat dalam empat bulan pertama pengobatan. Eliminasi HCV-RNA dalam minggu pertama pengobatan berkaitan dengan $76 \%$ probabilitas untuk mendapatkan respon permanen. Sedangkan bila HCV-RNA tetap positip setelah empat minggu pengobatan, maka probabilitas untuk mendapatkan respons permanen adalah $0 \%$. Hal ini menunjukkan bahwa eliminasi dini virus adalah sangat penting untuk mencapai respon permanen. Secara umum dapat disimpulkan bahwa dosis induksi IFN harian akan menghasilkan supresi virus yang lebih baik dibandingkan dengan dosis tiga kali seminggu.
\end{abstract}

\begin{abstract}
Development in the knowledge of biological aspects of hepatitis $C$ virus has lead to discovery of alternative therapeutic regimen. Alpha-interferon (IFN) represents the only drug approved for the treatment of chronic hepatitis- $C$ virus (HCV). However, relapse following withdrawal of thrice weekly therapy is noted in $50 \%$ of this patients. Some investigators have demonstrated that mutation can take place during the treatment with thrice weekly regimen. This is in agreement with the high HCV production and suggests that alternative regimen with daily induction dose would be more effective in preventing viral mutation. The reason for implementing daily induction therapy is to rapidly attain steady state concentration of the drug which is expected to totally inhibit virus replication and minimize the risk of mutation as seen with intermittent thrice weekly administration. Some investigators recently reported that patients with permanent response to IFN also showed rapid virus eradication during the first 4 months of treatment. HCV-RNA clearance within the first week of treatment is associated with $76 \%$ probability to have permanent response compared to $0 \%$ in patients whose $H C V-R N A$ remain positive after 4 weeks of treatment. It means that early virus elimination is very important to achieve permanent response. In general, daily IFN induction dose is associated with better virus suppression compared with three times weekly dose.
\end{abstract}

Keywords : Interferon, induction dose, hepatitis $C$

Hepatitis-C virus (HCV) infection affects more than $1 \%$ of world population and remains a public health problem. About $80 \%$ of acutely infected patients will develop chronic hepatitis which frequently leads to cirrhosis and hepatocellular carcinoma. ${ }^{1}$ Encouraging development in the knowledge of biological aspects of hepatitis-C virus is in progress; and the discovery of alternative therapeutic regimen based on this understanding is being examined in many clinical studies. $^{2}$

Department of Biology, Faculty of Medicine, UKRIDA

University, Jakarta, Indonesia
Today, alpha-interferon (IFN) represents the only drug approved for the treatment of chronic hepatitis-C virus (HCV). The recommanded dose is 3 million unit (MIU), three times a week for 24 weeks. Therapeutic response with this dose, as indicated by normalization of amino transaminase, is $40-50 \%$. However, relapse following withdrawal of therapy is noted in $50 \%$ of these patients. The virus does not always disappear in the blood of patients despite positive biochemical response to IFN. ${ }^{3}$

\section{Dynamic of HCV: The basis of new therapeutic strategy}

There are several predictive factors of therapeutic response to IFN, including virus load, virus genotype, 
quasi-species mutation and possible existence of IFNsensitivity determining region (ISDR). The diversity of these predictive factors indicates that treatment with IFN should be individualized. Although some patients show good response with three times a week administration of IFN, the others (including those infected by genotype-1 or those with high virus load) need more aggressive approach. In order to clarify this issue, some studies are conducted to evaluate the advantage of daily administration of IFN at the onset of the disease with the hope that this strategy would suppress viral replication and thereby, permanent virus eradication would be achieved. ${ }^{1}$

The reason for implementing daily induction therapy is to rapidly attain steady state concentration of the drug which is expected to totally inhibit virus replication and minimize the risk of mutation as has been seen by intermittent thrice weekly administration. ${ }^{1}$

By using a very sensitive and accurate method, Nguyen at al demonstrated that virus load is in steady state condition in non treated HCV-patient; with limited daily, weekly and monthly fluctuation of viral concentration. This indicates that virus load represents an acceptable marker of response to treatment. ${ }^{4}$

To determine whether the clearance of hepatitis-C virus genotype- 1 depends on the dose of interferon alpha-2b, Nancy Lam et al made a comparison of acute clearance of $\mathrm{HCV}$ after single administration of 3, 5 and $10 \mathrm{MIU}$ of IFN alpha 2-b. After 24 hours, the mean reductions of virus concentration in the serum were $41,4 \%, 63,7 \%$ and $85,5 \%$ respectively for the dose of 3,5 and $10 \mathrm{MIU}$ ( $\mathrm{p}<0.001$ ). After 48 hours, the virus reductions were lower: $22,9 \%, 61,9 \%$ and $74,3 \%$, respectively $(p<0.001)$. This indicates that the effect of this drug is diminished before 48 hours. Regression analysis showed a positive correlation between dose and percent reduction of HCV-RNA $(r=0.6, p<0.001)$. A mathematical model showed that dose dependency is expected if IFN-alpha partially blocks virus production. Minimum and average clearance of $\mathrm{HCV}$ productions as estimated by HCVRNA measurement after a dose of $10 \mathrm{MIU}$, which is a minimum estimation of daily $\mathrm{HCV}$ production and clearance, is $3.7 \times 10^{11}$ virion per day, which indicates that this virus has a high replication rate. This result showed the dependency of clearance of HCV genotype-1 on IFN doses. Considering a high replication rate of virion and unsatisfying efficacy of recommended dose ( $3 \mathrm{MIU}$ ) of IFN, a higher dose for the treatment of patients infected by HCV genotype-1, should be considered. ${ }^{3}$
Kinetic curve of $\mathrm{HCV}$ in patients receiving $3 \mathrm{MIU}$ of IFN thrice weekly showed that in some of them this dose is sufficient to eliminate the virus. However, a greater part of patients initially showed positive response to IFN (normalization of ALT after 2 or 3 month and reduction of virus), do not have viral eradication. If the therapy is stopped at the 6th month, HCV-RNA and ALT can increase rapidly in several weeks. This suggests that continuation of the treatment for a next 6 months could eradicate the virus (the virus is assumed to be sensitive to IFN therapy, but prolong treatment is needed for total eradication). ${ }^{2}$

Another group of patients have only minor or no response of HCV-RNA on the first month of therapy, and neither subsequent virus eradication, this group is called non-responder. Some investigators recently reported that patients with permanent response to IFN also showed rapid virus eradication during the first 4 months of treatment. ${ }^{5,6} \mathrm{HCV}$ RNA clearance within the first week of treatment is associated with $76 \%$ probability to have permanent response compared to $0 \%$ in patients whose HCV RNA remain positive after 4 weeks of treatment. ${ }^{7}$ It means that early virus elimination is very important to achieve permanent response.

\section{Dynamics of $\mathrm{HCV}$ supports rationality of daily IFN induction regimen}

Esomoto et al, and other investigators have demonstrated that mutation can take place during the treatment with thrice weekly regimen. This is in agreement with high $\mathrm{HCV}$ production and suggests that alternative regiment would be effective in preventing mutation. ${ }^{8}$ In a pilot study conducted at the University of Washington, 7 patients infected by genotype-1 HCV who developed bridging fibrosis and failed to cure by previous IFN treatment, received 10 MIU IFN everyday. These patients showed $1 / 22$ fold reduction of HCV RNA titer within 4-6 weeks of treatment. Virus elimination was achieved in 3 of 7 patients. This indicates that patients who do not respond to conventional IFN treatment with thrice weekly regimen can have benefit of re-treatment with higher daily induction dose. This preliminary results, along with recent data on dose-related reduction of viral load and the fact that HCV RNA mutation can take place with intermittent IFN doses, confirm rational of induction therapy in the management of $\mathrm{HCV}$ infection, especially in patients infected by genotype-1 $\mathrm{HCV},{ }^{2,3}$ 


\section{Daily induction dose}

A study has been performed by Dr. Stephanos Hadziyannis to compare the effect of daily induction dose of IFN alpha-2b with standard thrice weekly dose on the clearance and the number of viruses, in order to identify the dose-response relationship with this dose regimen. Patients recruited in this study (62 patients) received IFN alpha- $2 \mathrm{~b}$ ( 3,5 or 10 MIU) either as standard regimen three times a week or as daily dose for 2-4 weeks. Quantitative analysis of virus in each subjects was performed by Central laboratory for virology, (National Genetic Institute, California, USA). In general, daily IFN dose is associated with better virus suppression compared with three times weekly dose. Although moderate virus reduction is observed in patients receiving 3,5 or $10 \mathrm{MIU}$ IFN thrice weekly, the virus is still detected at the end of the $4^{\text {th }}$ week in the majority of patients. In contrast, daily dose gave more steep reduction of HCV RNA in the second week; 2-3 log reduction of virus is reported and in some patients and no virus was detected. At the $4^{\text {th }}$ week, the same reduction is still observed. This results indicate that daily dose of IFN alpha- $2 b$ results in earlier and more marked virus reduction. A higher dose is associated with better virus suppression. No withdrawal or dose reduction was needed during this study. The most frequent adverse even were mild fever (30/62 patients), myalgia (8/62) and depression, which was reported to be rare (4/62). Better tolerance to IFN was observed with daily dose, suggesting that steady state concentration of IFN is better tolerated than fluctuative concentration. This study indicated that daily dose is associated with earlier and more remarkable reduction of virus load when compared to thrice weekly dose. ${ }^{2}$

\section{Consensus panel of the Indonesian association for the study of the liver}

In the investigators meeting of The Indonesian Association for the study of the Liver held in Mataram, Lombok, on June 1998, regimen of chronic hepatitis $\mathrm{B}$ and $\mathrm{C}$ treatment was discussed. It was agreed that in a naive patient, IFN is to be given as induction therapy at the dose of 5 MIU everyday for 4 weeks, followed by $3 \mathrm{MIU}$ three times weekly up to 12 months; or induction therapy with daily dose of 5 MIU of IFN for 4 weeks followed by 3 MIU three times a week up to 6 month in combination with Ribavirin $1000 \mathrm{mg} /$ day. For relapse or non responsive cases, IFN is to be given everyday at a dose of 5 MIU for 4 weeks followed by $3 \mathrm{mIU}$ thrice weekly until 12 month in combination with Ribavirin $1000 \mathrm{mg} /$ day. $^{9}$

\section{CONCLUSION}

The use of induction therapy of high dose IFN alpha$2 b$ for 2-4 weeks followed by high maintenance dose three times a weeks represents an effective dose regimen. This regimen indicated that daily dose is associated with earlier and more remarkable reduction of virus load when compared to thrice weekly dose.

In the meeting of Indonesian Association for the Study of the Liver, daily induction dose of 5 MIU IFN for 4 weeks followed by $3 \mathrm{MIU}$ thrice weekly until 12 month or $3 \mathrm{MIU}$ thrice weekly in combination with Ribavirin $1000 \mathrm{mg} /$ day until 6 month was proposed as new treatment regimen.

\section{REFERENCES}

1. Beatriz Gavier et al. Viremia after one month of interferon therapy predicts treatment outcome in patients with chronic hepatitis C. Gastroenterology 1997;113:1647-53.

2. Hepatitis $C$ update. Daily induction dosing with IFN alfa$2 b$ in $\mathrm{HCV}$ infection. Reports from the $32^{\text {nd }}$ Annual Meeting of European Association for the Study of the Liver April 9-12, 1997, London, UK.

3. Nancy P Lam, Avidan U. Neumann, David R. Gretch, Thelma E. Wiley, Alan S.Perelson and Thomas J. Layden. Dose-dependent acute clearance of hepatitis C genotip 1 virus with interferon alfa. Hepatology $1997 ; 26(1): 226-31$.

4. Nguyen TT, Vaziri AS, Wilkes LB, Mondala T, Pockros PJ, Lindsay KL, McHutchison JG, Fluctuations in viral load (HCV RNA) are relatively insignificant in untreated patients with chronic $\mathrm{HCV}$ infection, J Viral Hepatitis, 1996 ; 3:75-8.

5. Orito et al. Loss of serum HCV RNA at week 4 of interferon- $\alpha$ therapy is associated with more favorable long-term response in patients with chronic hepatitis C. Journal Medical Virology 1995; 46: 109-15.

6. Sergi Ampurdanes et al. Permanent reśponse to alphainterferon therapy in chronic hepatitis $\mathrm{C}$ is preceded by rapid clearance of HCV-RNA from serum. Journal of Hepatology 1996; 25: 827-32.

7. Karino et al. Early loss of serum hepatitis $C$ virus RNA can predict a sustained response to interferon therapy in patients with chronic hepatitis C. Am J Gastroenterol 1997; 92:61-5.

8. Enomoto et al. Comparison of full-length sequences of interferon-sensitive and resistant hepatitis $\mathrm{c}$ virus $1 \mathrm{~b}$. J C Invest. 1995; 96: 224-30.

9. Proposal konsensus panel, Perhimpunan Peneliti Hati Indonesia Mataram, Lombok Juni 1998. 